\title{
Audit Committee Features and CSR Disclosure: Additional Evidence From an Emerging Market
}

\author{
Sumaia Ayesh Qaderi ${ }^{1}$, Turki Raji Alhmoud ${ }^{2} \&$ Belal Ali Abdulraheem Ghaleb ${ }^{1}$ \\ ${ }^{1}$ Department of Accounting, Hodeidah University, Hodeidah, Yemen \\ ${ }^{2}$ Department of Accounting, Yarmouk University, Irbid, Jordan \\ Correspondence: Sumaia Ayesh Qaderi, Department of Accounting, Hodeidah University, Hodeidah, Yemen. E-mail: \\ sumaia.qaderi.2020@gmail.com
}

Received: July 11, 2020

Accepted: September 6, 2020

Online Published: October 4, 2020

doi:10.5430/ijfr.v11n5p226

URL: https://doi.org/10.5430/ijfr.v11n5p226

\begin{abstract}
This study aims to measure the level of corporate social responsibility disclosure (CSRDL) in an emerging market, Jordan. It also aims to investigate the effect of audit committee (AC) features on CSRDL. The study's data, obtained from annual reports, comprises 576 company-year observations from industrial and services companies listed on the Amman stock exchange for the period 2011 to 2016. Content analysis is used to measure CSRDL, and multiple regression techniques to test the proposed relationships. The results show that CSRDL among Jordanian listed companies is low, suggesting that companies have less incentive to disclose CSR practices. Additionally, AC independence and AC ownership positively influence CSRDL. The findings from this research have limited generalisability due to the specific characteristics of the sample, which is from a developing country. However, they have implications and value for policymakers and different stakeholders interested in improving CSR initiatives. The findings are also significant in reducing agency costs and enhancing corporate transparency. Within the limits of the authors' knowledge, this research is among the first to provide preliminary evidence on the effect of AC features on CSR disclosure in an emerging market context, specifically in Jordan.
\end{abstract}

Keywords: audit committee, corporate governance, disclosure, corporate social responsibility, Jordan

JEL: M21, G34, M41, M42

\section{Introduction}

There has been an upsurge in financial crises, cases of corruption and environmental hazards in recent years. These have a significant effect from the economic, social, and environmental perspectives. Because of these contemporary challenges, corporate social responsibility (CSR) reporting is being emphasised by government authorities, capital providers, stakeholders, academics, professionals, and society as a whole, as these parties are pressuring companies to accept greater responsibility for sustainable development (Aguinis \& Glavas, 2012; Garcia et al., 2020). Well-known cases of fraud and corporate scandals like those of Enron, WorldCom, American insurance group, Lehman Brothers and Meadow have shown that contemporary corporate governance should dwell more on ethics, accountability and social responsibility and the need to tackle agency conflicts (Elkington, 2006). Consequently, corporate stakeholders now demand more understanding of how business decisions and strategies incorporate considerations of social, environmental and economic issues (Amran \& Ooi, 2014). CSR activities are considered as one of the important strategies that allow companies to attract institutional investment, as these investors have no concern with companies that actively engage in community contribution practices (Daas \& Alaraj, 2019).

The audit committee (AC) constitutes a corporate governance mechanism that enhances the integrity of financial and non-financial reporting. It is the most strategic of the committees in the financial reporting system (Ali \& Kamardin, 2018). It is important to emphasise the quality of ACs because they are directly involved in providing information to the public. This information should be credible and contain more disclosure to meet stakeholders' expectations and to mitigate the asymmetry of information ( $\mathrm{Li}$ et al., 2012). Studies have extensively examined the relationship between AC characteristics and CSR disclosure, and tend to agree on the positive role of the existence and characteristics of the AC on enhancing CSRDL (Appuhami \& Tashakor, 2017; Garas \& ElMassah, 2018; Khan et al., 2013; Said et al., 2009). However, the effect of AC features on CSRDL in Jordan is not yet clear. To the best of the 
researchers' knowledge, there is an absence of empirical studies addressing this relationship in the Jordanian market. Limited disclosure of data about AC characteristics in the companies' annual reports could be a reason for this dearth of studies. Further, previous studies have not examined the relationship between AC shares ownership and AC effectiveness and CSRDL. Thus, the current study fills this gap in the literature.

ACs and CSR activities are a concern of regulatory bodies in Jordan. The Jordan Securities Commission (JSC) recommended the board of directors of listed companies to establish ACs comprising three non-executive directors, with a minimum of two being independent. In addition, the JSC emphasises that all AC members should have financial and accounting literacy, and at least one financial expertise or an accounting and audit qualification (JSC, 2009). Under CSR, listed companies are required to disclose information related to social activities, such as their policies for protecting the natural environment, serving the community, or making grants to their human resources (Abu Qa'dan \& Suwaidan, 2019; Suwaidan et al., 2004). Therefore, the current study aims to measure CSRDL. It also aims to examine how $\mathrm{AC}$ features (size, independence, financial expertise, and ownership) determine the CSRDL among Jordanian public companies. It analyses annual reports of selected Jordanian companies listed on the Amman stock exchange (ASE) for the period 2011 to 2016 (576 company-year observations). The study findings indicate that companies in the Jordanian market provide a low CSRDL. They also show that AC independence and ownership positively and significantly influence CSR disclosure. However, AC size and AC financial expertise have no significant influence on CSRDL. Additional tests also show that AC effectiveness does not enhance CSRDL.

This research contributes to knowledge in different ways. First, it presents additional evidence to the limited empirical literature in the area of CSR disclosures among developing countries. It supports the previous evidence that CSR disclosure is still low in these countries in comparison to developed countries. Second, by investigating the link between AC and CSR disclosure, this research adds to the prior corporate governance literature, particularly in Jordan. Third, this study has implications for policymakers, regulators, and practitioners in Jordan about the urgency of CSR reporting improvement and how to encourage companies to implement it.

The remainder of the paper continues as follows. The next section reviews the theoretical and empirical literature on CSR disclosure and AC characteristics and develops the hypotheses. The study's methodology is presented in section three. Section four describes the results and discusses them in relation to the literature. Section five concludes the study with some policy implications and suggestions for future research.

\section{Literature Review and Hypothesis Development}

\subsection{CSR Theoretical Background}

Over the last two decades, several studies on CSR disclosure have contributed to further theoretical development and their practical application in the business world. This research is based on two theories: legitimacy and agency theories (Garcia et al., 2020). From the legitimacy perspective, companies' CSR disclosure practices constitute a tool for establishing and maintaining their legitimacy because CSR affects several important stakeholders (Tilt \& Symes, 1999). Hence, corporate CSR disclosures may be utilised to show the extent to which the organisation conforms to the expectations of the wider society (Deegan et al., 2002). Companies are expected to disclose a sufficient level of financial and non-financial information to serve as evidence that they comply with societal expectations and conduct their operations within the limit considered acceptable by stakeholders (Wilmshurst \& Frost, 2000). Numerous studies suggest that legitimacy theory is appropriate in understanding CSR disclosures as a way of improving companies' image and legitimising their actions (Barakat et al., 2015; Dyduch \& Krasodomska, 2017; Garas \& ElMassah, 2018; Sadou et al., 2017). The second theory employed here is agency theory, under which the AC is considered to be an internal monitoring mechanism in the financial and non-financial reporting process that attempts to mitigate the conflict problem (Jensen \& Meckling, 1976; Madi et al., 2014); this may lead to improved performance and higher quality of CSR disclosure. The literature suggests that the presence of an effective AC will improve the disclosure quality and internal control system while helping to mitigate agency costs (Appuhami \& Tashakor, 2017; Madi et al., 2014; Setiany et al., 2017).

Recently, many studies have indicated growing interest in CSR disclosure (e.g. Alazzani et al., 2019; Garcia et al., 2020). Researchers argue that it performs a vital function in enhancing the quality of communication among stakeholders (De Klerk et al., 2015). Additionally, research in emerging and advanced contexts has focused on the relationship between corporate governance proxies and CSR disclosure, providing inconsistent evidence regarding the manner in which corporate governance influences CSR disclosure (e.g. Garas \& ElMassah, 2018; Khan et al., 2013; Majumder et al., 2017; Wu et al., 2012). Furthermore, a study conducted in Australia (Appuhami \& Tashakor, 2017) focused on determining how AC characteristics influence CSR disclosure. 
In Jordan, there has been limited research on CSR disclosure. The little available work concentrated on the factors that influence CSR disclosure in companies (Abu-Baker \& Naser, 2000; Abu Farha \& Alkhalaileh, 2016; Abu Qa'dan \& Suwaidan, 2019; Al-Hamadeen \& Badran, 2014; Alshannag et al., 2016; Barakat et al., 2015; Ismail \& Ibrahim, 2008; Suwaidan et al., 2004). Most of these studies investigated the CSRDL in Jordan utilising content analysis. Their findings show that CSRDL is very low, especially when compared to developed countries. To cite one instance, Suwaidan et al. (2004) find that a company only reported around 13 per cent of the items included in the index, while only three companies had CSR disclosure scores above 30 per cent. In the work of Ismail and Ibrahim (2008), 15 per cent of the sampled businesses did not provide a report regarding CSR activities. The results of the study by Al-Hamadeen and Badran (2014) reveal that the average CSR disclosure score for the fiscal year 2011 was about 19 per cent, whereas Alshannag et al. (2016) find that the average level of CSR disclosure in the services and industrial sectors from 2011 to 2014 was about 34.1 per cent. Similarly, Abu Qa'dan and Suwaidan (2019) report an average of CSR disclosure level of 30.80 per cent. These findings point to a serious need for more CSR disclosure among companies in Jordan if they are to be compared with more developed economies.

Research on how corporate governance affects CSR information disclosure in Jordan is limited and provides inconsistent results (Abu Qa'dan \& Suwaidan, 2019; Ibrahim \& Hanefah, 2016). Ibrahim and Hanefah (2016) looked at board diversity features and how they affect CSRDL. Using a sample of 117 companies registered on the ASE from 2007 to 2011, they found that directors' independence and having women, foreign and young members on the board all significantly and positively affect CSR disclosure. However, it was revealed that profitability did not play a significant role in the decision to disclose CSR activities. Abu Qa'dan and Suwaidan (2019) found that board size is significantly and positively associated with CSRDL. However, the proportion of independent directors, the duality of CEO, board ownership, director's age, and institutional ownership have no impact on CSRDL. The effect of the AC on CSR, to the best of the researchers' knowledge, has not yet been addressed. Thus, the current study fills this gap in the literature.

\subsection{Audit Committee Features and CSR Disclosure}

The AC is an important link between the board of directors, management, internal and external auditors (Ahmed Haji \& Anifowose, 2016). Thus, the presence of an AC is expected to improve communication between owners and management (Barako et al., 2006), reduce information asymmetry, enhance disclosure quality and improve market performance (Said et al., 2009). Additionally, the presence of the AC in public corporations reduces agency cost (Forker, 1992), which could improve corporate performance. Consistent with agency theory, the AC can act as a watchdog that promotes corporate disclosure and enhances transparency. This assures stakeholders and assists management in securing finance. Previous studies on the AC suggest that its effectiveness depends on certain features (Akhtaruddin \& Haron, 2010; Dhaliwal et al., 2010; Li et al., 2012; Persons, 2009). Therefore, a suitable mix of experiences and skills is vital in enabling the AC to perform effectively. In view of this argument, some hypotheses are proposed and investigated in the present study to determine the influence of AC characteristics (size, independence, financial expertise, and share ownership) on CSRDL.

\subsubsection{Audit Committee Size (ACSIZE) and CSR Disclosure}

Larger ACs have the capacity, diverse expertise and perspectives to ensure appropriate oversight (Bédard et al., 2004) of CSR disclosure. They may reduce the likelihood of information asymmetry and the agency problem (Chen \& Jaggi, 2000). Mangena and Pike (2005) assert that a larger AC results in better oversight because it is more likely to be made up of the necessary expertise and skills. Previous empirical research yielded mixed results regarding the role of AC size. For example, some authors reported that $\mathrm{AC}$ size positively influences the extent of voluntary disclosure (Madi et al., 2014; Persons, 2009; Setiany et al., 2017). Similarly, Appuhami and Tashakor (2017) found that AC size positively influences the extent of CSR disclosure while other studies found no significant effect of AC size on voluntary ethics disclosure (e.g. Othman et al., 2014). In line with the proposition of agency theory, it is expected that larger ACs will possess a greater capacity for board monitoring to improve the level of CSR disclosure. Therefore, the following hypothesis is formulated:

H1: The AC size positively influences the level of CSR disclosure.

\subsubsection{Audit Committee Independence (ACIND) and CSR Disclosure}

For ACs to be effective, they need to be free from top management influence (Lin et al., 2008). In line with agency theory, independent directors are more inclined to oversee management's activities and to increase disclosure. This reduces information asymmetry and agency conflicts to the minimum (Fama \& Jensen, 1983). As noted by Fama (1980), including independent directors from outside the company decreases the chance of collusion among the 
management team and prevents expropriation of the assets of shareholders. Some past studies related to the subject found a positive effect of AC independence on the voluntary financial disclosure level (Akhtaruddin \& Haron, 2010; Setiany et al., 2017). Garas and ElMassah (2018) found a positive effect of AC independence on CSRDL. In contrast, Othman et al. (2014) reported an insignificant positive effect of AC independence on voluntary ethics disclosure. Therefore, the current research investigates the influence of AC independence on CSR disclosure. In pursuance of this objective, the following hypothesis is proposed:

$\mathrm{H} 2$ : AC independence positively affects the level of CSR disclosure.

\subsubsection{Audit Committee Financial Expertise (ACEXP) and CSR Disclosure}

Based on the agency theory, the corporate board, particularly the AC, needs critical expertise and skills to supervise management and to monitor the preparation of financial reports effectively (Fama \& Jensen, 1983). Essentially, members of the AC should possess a certain level of financial literacy to enable them to understand and interpret financial reports (Dhaliwal et al., 2010). According to Bédard and Gendron (2010), expertise in the area of finance enables AC members to probe deeper and ask vital questions which challenge management and auditors. This will lead to higher quality financial statements. It will also improve the transparency of financial reports and keep agency conflict to the barest minimum. Persons (2009) asserts that independent AC members who also possess accounting skills have a higher probability of detecting irregularities in financial statements, and other inappropriate transactions. Such members are more diligent because they need to protect their professional image and code of ethics.

Empirical studies that examined the influence of AC financial expertise on CSRDL are few and provide mixed results. For instance, Madi et al. (2014) found that AC financial expertise did not significantly influence the voluntary disclosure level. Likewise, Appuhami and Tashakor (2017) reported an insignificant association between AC financial expertise and CSRDL. However, Mangena and Pike (2005) and Felo and Solieri (2009) reported a positive and significant link between these two variables. Therefore, the following hypothesis is formulated:

H3: AC financial expertise has a positive effect on the level of CSR disclosure.

\subsubsection{Audit Committee Share Ownership (ACOWN) and CSR Disclosure}

There are two schools of thoughts regarding the influence of share ownership of the AC members on the company's disclosure level. From the point of view of the agency theory, the first argues that the interests of directors who hold a high proportion of company shares will be more closely aligned to those of other shareholders. It is also expected that they may be more zealous in overseeing management activities, which could improve the financial reporting system and encourage a higher quality of disclosure to the capital market (Karamanou \& Vafeas, 2005). However, a contrary argument is that higher AC share ownership may cause weak oversight of the members because they would tend to act in their own interest at the expense of other shareholders. This may have a negative impact on their effectiveness (Mangena \& Pike, 2005).

Previous researchers did not directly investigate the link between CSR disclosure and AC share ownership. However, some authors ( $\mathrm{Li}$ et al., 2012; Mangena \& Pike, 2005) provide indirect evidence of a significant negative effect of AC share ownership on the extent of voluntary disclosure. Therefore, the following hypothesis is established:

H4: AC share ownership has an effect on the level of CSR disclosure.

\section{Data and Methodology}

\subsection{Sampling and Data}

The sample of the current study includes all non-financial Jordanian companies listed in the ASE between 2011 and 2016. Companies operating in the finance sector (e.g., banks, insurance, and diversified financial services) were excluded because they have special regulatory provisions and are subject to peculiar corporate governance laws which differ from other registered companies (Rainsbury et al., 2009). A company with missing data is also excluded. The final sample is 96 companies (576 company-year observations) in two sectors: industrial and services. These two sectors have more impact on society and the surrounding environment (Ismail \& Ibrahim, 2008). The sample is summarised in Table 1.

Annual reports of the Jordanian companies are the main source of data, supplemented by board of directors and ownership disclosures submitted separately to the ASE, and formal contact with companies to gather the AC missing data. 
Table 1. Sample of study

\begin{tabular}{lc}
\hline Explanation & No. of Companies \\
\hline All companies listed in the ASE & 200 \\
Excluded companies: & \\
Financial companies & 103 \\
Missing data at any time between 2011 and 2016 & 1 \\
Total excluded companies & $(104)$ \\
The final sample & 96 \\
Total of observations $(96$ companies *6 years) & 576 \\
\hline
\end{tabular}

\subsection{Variables Measurement}

\subsubsection{Level of CSR Disclosure Measurement}

Content analysis was used in extracting CSR data from companies' annual reports. Content analysis is a technique for gathering data and codifying both qualitative and quantitative information into pre-determined categories to assist in the presentation and communication of vital information (Krippendorff, 2018). The study utilised the CSR checklist relevant to Jordanian companies used by Abu Qa'dan and Suwaidan (2019). This checklist consists of information in four categories of activity (community involvement, environmental, products/services to customers and human resources) covering an inventory of 42 items. A dichotomous scoring technique was utilised such that a company is scored 1 if a checklist item is disclosed and 0 otherwise. Therefore, the CSR disclosure index was arrived at by computing the ratio of actual scores to the maximum obtainable (42) by that company. As in Abu Qa'dan and Suwaidan' (2019) procedure, the CSR disclosure index was calculated as:

$$
\text { CSR disclosure score }{ }_{i, t}=\frac{\sum_{1}^{42} d_{i, t}}{42}
$$

Where: $\mathrm{d}=1$ if the item $\mathrm{i}$ is disclosed and 0 otherwise; and $\mathrm{t}=$ the time (year). So that, 0 per cent $\leq \mathrm{CSR}$ disclosure score $\leq 100$ per cent.

\subsubsection{Independent and Control Variables Measurement}

Independent variables in our research model are AC features (AC size, AC financial expertise, AC share ownership and $\mathrm{AC}$ independence). Previous studies suggest that it is important to control for company characteristics when examining CSR disclosure (Kansal et al., 2014; Ting, 2020; Wachira et al., 2019). Several variables that may affect CSR disclosure are therefore controlled for in the model: ownership concentration (OWC) (Crifo et al., 2016); audit fees (AFEE) (Chen et al., 2016); return on assets (ROA); market to book ratio (MTB); company size (CSIZE) (Ghaleb et al., 2020b); and debt ratio (DEBT). The regressions also include sector type and year indicator variables to further control for any industry and year effects. Definitions and measures of the variables investigated in this study are summarised in Table 2.

\subsection{Model Specification}

To determine the influence of AC features on CSRDL in the Jordanian market, we estimate the following ordinary least squares (OLS) regression model with robust standard errors (Alazzani et al., 2019; Appuhami \& Tashakor, 2017). We winsorise all variables that have extreme values to overcome the effect of the outlier (Harper \& Sun, 2019):

$C S R D L=\beta_{0}+\beta_{1} A C S I Z E+\beta_{2} A C I N D+\beta_{3} A C E X P+\beta_{4} A C O W N+\beta_{5} O W C+\beta_{6} A F E E+\beta_{7} R O A+\beta_{8} M T B+\beta_{9}$ $C S I Z E+\beta_{10} D E B T+\beta_{11}$ SECTOR TYPE $+\beta_{12}$ YEAR DUMMIES $+\epsilon$

Where:

CSRDL $=$ CSR disclosure level; $\beta_{0}=$ Intercept; $\beta_{1-11}=$ Variables coefficients; Year is the period of study; and $\epsilon=$ Error term (see Table 2 for variables definitions). 
Table 2. Variables measurement

\begin{tabular}{|c|c|c|c|}
\hline Variable & Acronym & Proxy /Measurement & References \\
\hline $\begin{array}{l}\text { CSR disclosure } \\
\text { level }\end{array}$ & CSRDL & $\begin{array}{l}\text { an unweighted measure of CSRDL, " } 0,1 \text {,, } \\
\text { with total disclosure score } 42 \text {. }\end{array}$ & (Abu Qa'dan \\
\hline AC size & ACSIZE & Total number of AC members & \& Suwaidan, \\
\hline AC independence & ACIND & the proportion of independent members in $\mathrm{AC}$ & 2019 \\
\hline $\begin{array}{l}\text { AC financial } \\
\text { expertise }\end{array}$ & ACEXP & $\begin{array}{l}\text { the proportion of } \mathrm{AC} \text { members with financial } \\
\text { qualification }\end{array}$ & $\begin{array}{l}\text { Appuhami \& } \\
\text { Tashakor, }\end{array}$ \\
\hline AC ownership & ACOWN & $\begin{array}{l}\text { the proportion of shares owned by } \mathrm{AC} \\
\text { members }\end{array}$ & $\begin{array}{l}\text { 2017; Barakat } \\
\text { et al., 2015; }\end{array}$ \\
\hline $\begin{array}{l}\text { Ownership } \\
\text { concentration }\end{array}$ & OWC & $\begin{array}{l}\text { the proportion of shares held by the largest } \\
\text { shareholder }\end{array}$ & $\begin{array}{l}\text { Ghaleb et al., } \\
\text { 2020a; }\end{array}$ \\
\hline Audit fees & AFEE & natural log of audit fees & Ghaleb et al., \\
\hline Return on assets & ROA & net income divided by total assets & 2020b; Khan \\
\hline $\begin{array}{l}\text { Market to book } \\
\text { value ratio }\end{array}$ & MTB & market value divided by book value per share & $\begin{array}{l}\text { et al., 2013; } \\
\text { Madi et al., }\end{array}$ \\
\hline Company size & CSIZE & natural log of total assets & 2014; Setiany \\
\hline Debt ratio & DEBT & total liabilities divided by total assets & et al., 2017; \\
\hline Sector type & SECTYPE & $\begin{array}{l}\text { dummy variable: } 1=\text { industry sector, } \\
0=\text { otherwise }\end{array}$ & Ting, 2020) \\
\hline
\end{tabular}

\section{Results}

\subsection{Descriptive Statistics}

Descriptive analysis results are reported in Table 3. The mean CSRDL for the study period 2011-2016 is 0.293, indicating that, on average, Jordanian listed companies disclose 29.3 per cent of the items contained in the CSR checklist in their yearly statements, that is a low CSRDL. However, this result is similar to that of Abu Farha and Alkhalaileh (2016) and Abu Qa'dan and Suwaidan (2019). Importantly, CSRDL for each year (untabulated) is almost invariable, suggesting that companies did not increase their percentage of CSR item disclosure over the period of study. The statistics in Table 3 also show that the number of directors on the AC (ACSIZE) ranges from two to five with a mean of approximately 3.106. The mean proportion of companies with independent AC members (ACIND) is around 78.6 per cent. This shows that most companies have ACs with independent directors. On average, 58.8 per cent of AC members have financial expertise (ACEXP). This encompasses academic and professional qualifications/experience in finance or accounting. In terms of $\mathrm{AC}$ ownership (ACOWN), the average is approximately 3.7 per cent over time.

Table 3. Descriptive statistics for continuous variables

\begin{tabular}{lcccccc}
\hline Variable & $\mathbf{N}$ & Mean & SD & $\mathbf{2 5 \%}$ & Median & $\mathbf{7 5 \%}$ \\
\hline CSRDL & 576 & 0.293 & 0.128 & 0.21 & 0.29 & 0.36 \\
ACSIZE & 576 & 3.106 & 0.410 & 3.00 & 3.00 & 3.00 \\
ACIND & 576 & 0.786 & 0.289 & 0.67 & 1.00 & 1.00 \\
ACEXP & 576 & 0.588 & 0.312 & 0.33 & 0.67 & 1.00 \\
ACOWN & 576 & 0.037 & 0.087 & 0.00 & 0.00 & 0.02 \\
OWC & 576 & 0.611 & 0.230 & 0.46 & 0.65 & 0.80 \\
ROA & 576 & 0.023 & 0.096 & -0.01 & 0.03 & 0.06 \\
CSIZE & 576 & 17.112 & 1.473 & 16.25 & 17.09 & 17.85 \\
DEBT & 576 & 0.324 & 0.220 & 0.16 & 0.29 & 0.42 \\
AFEE & 576 & 9.402 & 0.826 & 8.92 & 9.23 & 9.66 \\
MTB & 576 & 1.342 & 1.144 & 0.66 & 1.00 & 1.71 \\
\hline
\end{tabular}

Note: Variables definitions are presented in Table 2.

For the control variables, Table 3 shows that companies in Jordan have highly concentrated ownership by families or government (Abu Qa'dan \& Suwaidan, 2019). The mean ownership concentration (OWC) is around 61.148 per cent 
over the period of the sample. Moreover, the mean of audit fees (AFEE) is 9.402, where the average of the return on assets (ROA) is 2.30 per cent. The average market to book value ratio (MTB) is 1.34 . Further, the statistics show that the mean company size (CSIZE) as measured by the natural log of total assets is 17.112 , and the mean debt ratio (DEBT) is 32.4 per cent.

The correlation matrix between variables is illustrated in Table 4. The results show a positive relationship between AC size, AC independence, AC financial expertise and CSRDL. However, there is a negative correlation between AC ownership and CSRDL. The results show a high correlation between audit fees and firm size, which is not surprising given that the larger companies invest more in external audit. Importantly, Table 4 shows that multicollinearity is not a serious problem among the variables, as the coefficients of the relationships are below the critical level of 0.80 (Greene, 2003). Furthermore, variance inflation factors (VIF) were calculated to test for potential multicollinearity. According to Greene (2003), multicollinearity exists when the VIF value is more than 10. In this study, VIFs range from 1.08 to 2.66, so multicollinearity was not detected (see Table 4). Moreover, this study applied the Breusch-Pagan/Cook-Weisberg tests to detect any linear form of heteroscedasticity and the Durbin-Watson test to investigate autocorrelation of the error terms. The results show that the data suffer from autocorrelation. Thus, OLS regression with a robust function was employed (Alazzani et al., 2019; Appuhami \& Tashakor, 2017).

Table 4. Correlation matrix

\begin{tabular}{|c|c|c|c|c|c|c|c|c|c|c|c|c|}
\hline Variables & CSRDL & ACSIZE & ACIND & ACEXP & ACOWN & OWC & AFEE & ROA & MTB & CSIZE & DEBT & VIF \\
\hline CSRDL & 1 & & & & & & & & & & & \\
\hline ACSIZE & $0.099^{* *}$ & 1 & & & & & & & & & & 1.12 \\
\hline ACIND & $0.250 * * *$ & 0.026 & 1 & & & & & & & & & 1.64 \\
\hline ACEXP & $0.095^{* *}$ & 0.034 & $0.077 *$ & 1 & & & & & & & & 1.08 \\
\hline ACOWN & $-0.079^{*}$ & 0.06 & $-0.555^{* * *}$ & 0.005 & 1 & & & & & & & 1.55 \\
\hline OWC & 0.007 & $0.107 * *$ & $-0.092 * *$ & $0.085^{* *} *$ & 0.005 & 1 & & & & & & 1.12 \\
\hline AFEE & $0.538 * * *$ & $0.166^{* * *}$ & $0.320 * * *$ & $0.208 * * *$ & $-0.191 * * *$ & $0.178 * * *$ & 1 & & & & & 2.46 \\
\hline ROA & $0.201 * * *$ & -0.02 & $0.077^{*}$ & 0.057 & $0.073^{*}$ & $0.103 * *$ & $0.120 * * *$ & 1 & & & & 1.28 \\
\hline MTB & $0.113 * * *$ & $0.193 * * *$ & $-0.107 * *$ & -0.062 & $0.114 * * *$ & $0.156^{* * *}$ & $0.108^{* *}$ & $0.105^{* *}$ & 1 & & & 1.17 \\
\hline CSIZE & $0.581 * * *$ & $0.222 * * *$ & $0.252 * * *$ & $0.167 * * *$ & $-0.178 * * *$ & $0.166^{* * * *}$ & $0.744 * * *$ & $0.238 * * *$ & $0.081 *$ & 1 & & 2.66 \\
\hline DEBT & $0.209 * * *$ & $0.085^{* *}$ & $0.117 * * *$ & $-0.085^{* *}$ & $-0.200 * * *$ & $-0.070^{*}$ & $0.294 * * *$ & $-0.238 * * *$ & $0.182 * * *$ & $0.337 * * *$ & 1 & 1.43 \\
\hline
\end{tabular}

Note: $* * * \mathrm{p}<0.01, * * \mathrm{p}<0.05, * \mathrm{p}<0.10$. Variables definitions are presented in Table 2.

\subsection{Multivariate Analysis}

Table 5 depicts the empirical results of the multiple linear regression between the AC characteristics and CSRDL to investigate our hypotheses. The regression model tests whether the features of AC increase the level of overall CSR disclosure. The model is significant at the 1 per cent level ( $\mathrm{R}$-squared $=0.50, \mathrm{p}$-value $<0.01$ ). This shows that the regression model can account for about 50 per cent of the variance in CSRDL, and this is explained by the independent variables in the model.

Based on the results presented in Table 5, the coefficient of AC size is negative but not significantly associated with CSRDL (t-value $=-0.05, \mathrm{p}>0.10$ ). Thus, $\mathrm{H} 1$ is rejected, suggesting that ACSIZE has no effect on CSRDL in the Jordanian market. However, this result is in contrast to previous studies (Appuhami \& Tashakor, 2017) that report a significant positive association between AC size and CSRDL.

Moving on to the second hypothesis, the results show that AC independence (ACIND) has a significant and positive association with CSRDL at 1 per cent ( $\mathrm{t}$-value $=4.31, \mathrm{p}<0.01$ ). Thus, $\mathrm{H} 2$ is supported. This is consistent with agency theory, that emphasises the importance of directors' independence in enhancing financial reporting quality. It is also in line with previous empirical studies' findings (e.g. Appuhami \& Tashakor, 2017; Setiany et al., 2017; Garas \& ElMassah, 2018) which report a positive influence of AC independence on the level of corporate disclosure. This result affirms the argument that having independent directors on the AC strengthens its performance. Therefore, it can be argued that an independent AC provides more effective oversight of the information provided in companies' annual reports. 
The results in Table 5 reveal that AC financial expertise (ACEXP) has no significant association with CSRDL (t-value $=-0.02, \mathrm{p}>0.10)$. Thus, $\mathrm{H} 3$ is rejected. This is consistent with Appuhami and Tashakor (2017) and Othman et al. (2014). A possible reason is that AC members with financial expertise pay more attention to the financial processes and transactions than to CSR activities and disclosure (Appuhami \& Tashakor, 2017). Regarding AC ownership (ACOWN), the coefficient is strongly and positively related to CSRDL $(t=3.95, p<0.01)$. Thus, H4 is supported. This can be interpreted to mean that AC ownership is vital in improving CSR disclosure and reducing the information asymmetry associated with agency problems between shareholders and managers. The results support the positive influence of directors' and managers' incentives predicted by agency theory (alignment hypothesis). However, the result contradicts other studies that show the relationship to be negative (Li et al., 2012).

Regarding control variables, the results reported in Table 5 show that ownership concentration is negatively and significantly associated with CSRDL. This result is in line with the claim that larger shareholders have interests other than CSR activities (Crifo et al., 2016). Thus, companies with high ownership concentration consider CSR activities as a cost rather than an investment that may contribute to the company value. Similar to the results of another study (Chen et al., 2016), our results show that audit fees are positively and significantly associated with CSRDL. Company characteristics ROA, MTB, CSIZE, and DEBT were found to be positively associated with CSRDL, suggesting that these characteristics have a significant role in enhancing CSRDL.

Table 5. Regression results of audit committee features and CSRDL

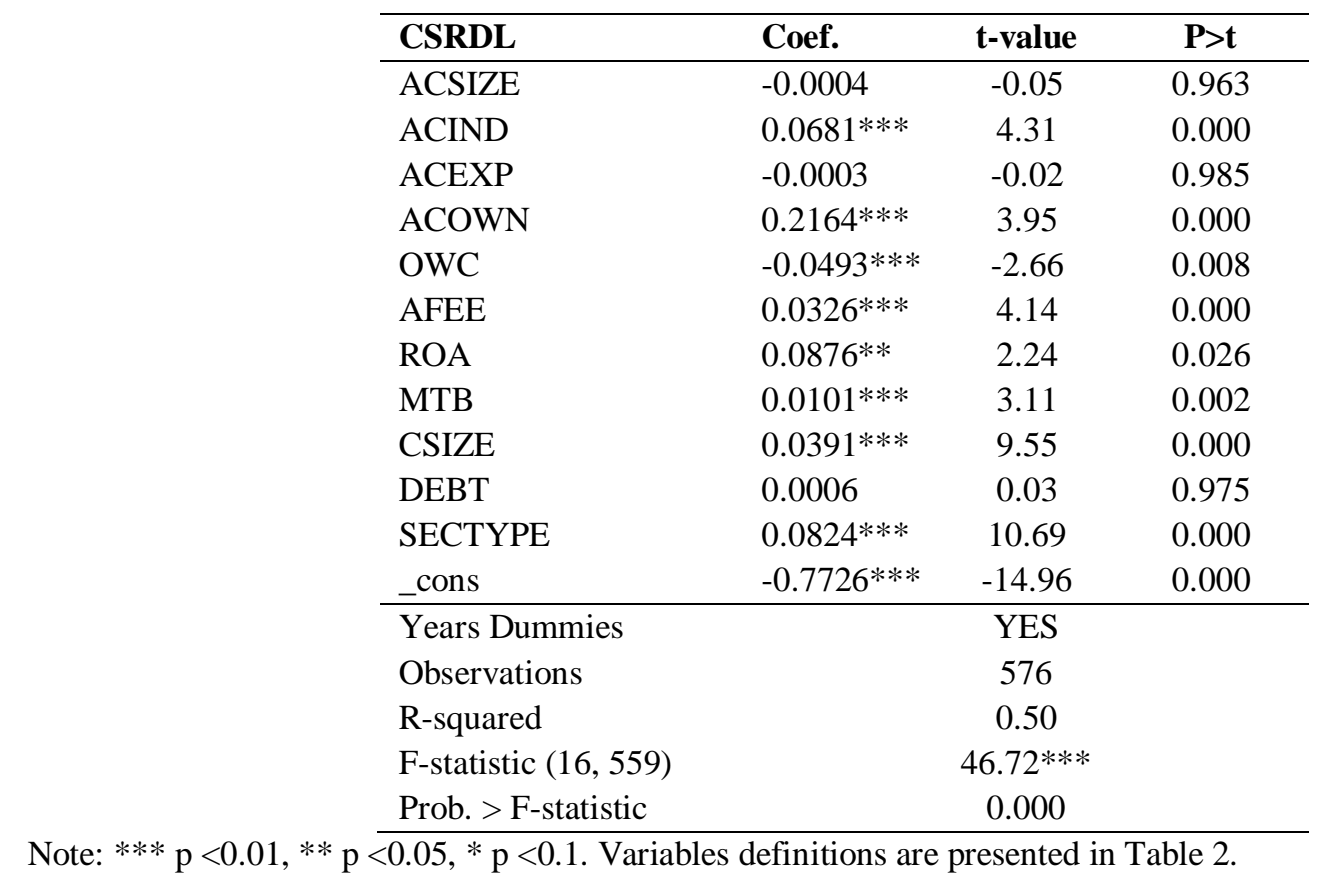

\subsection{Additional Tests}

Recent research emphasises that AC measured through a composite score of its characteristics can better capture the AC's effectiveness (ACE) in monitoring financial reporting, as these characteristics complement each other (e.g., Lisic, 2014; Zaman et al., 2011). Therefore, we measure the AC features using binary variables (dummies). ACSIZEdum equals 1 if the $\mathrm{AC}$ has more than three members, and 0 otherwise. ACINDdum equals 1 if the AC is fully independent (all members are independent), and 0 otherwise. ACEXPdum equals 1 if the $\mathrm{AC}$ has at least one member with financial expertise, and 0 otherwise. ACOWNdum equals 1 if any AC member owns shares in the company and 0 otherwise. Finally, we score all dummies to measure the ACE and examine its influence on CSRDL. The results reported in Table 6 show that ACE has no significant influence on CSRDL. Overall, the results suggest that the role of $\mathrm{AC}$ in the Jordanian market is still inadequate, although some individual characteristics show a positive association with CSRDL. 
Table 6. Regression results of audit committee effectiveness and CSRDL

\begin{tabular}{llcc}
\hline CSRDL & Coef. & t-value & P>t \\
\hline ACE (score) & -0.0035 & -0.67 & 0.503 \\
OWC & $-0.0643^{* * *}$ & -3.25 & 0.001 \\
AFEE & $0.0390^{* * *}$ & 4.90 & 0.000 \\
ROA & $0.1074^{* * *}$ & 2.69 & 0.007 \\
MTB & $0.0097^{* * *}$ & 2.86 & 0.004 \\
CSIZE & $0.0387^{* * *}$ & 9.35 & 0.000 \\
DEBT & -0.0086 & -0.42 & 0.678 \\
\hline Sector \& Year & & Yes & \\
Observations & & 576 & \\
R-squared & & 0.485 & \\
F-statistic (16, 559) & & $55.88^{* * *}$ & \\
Prob. > F-statistic & & 0.000 & \\
\hline
\end{tabular}

Note: $* * * \mathrm{p}<0.01, * * \mathrm{p}<0.05, * \mathrm{p}<0.10$. ACE is AC effectiveness measured as a composite score of the dummies of four AC features (ACSIZEdum, ACINDdum, ACEXPdum, and ACOWNdum). Definitions of other variables are presented in Table 2.

\section{Conclusions}

The research was conducted to investigate the effect of AC characteristics on CSRDL among Jordanian listed companies over the six years 2011 to 2016. Specifically, making use of agency theory, it tests the effect of several features (size, independence, financial expertise, and ownership) as determinants of CSR disclosure. The results reveal that the presence of independent AC members and AC ownership has a positive impact on CSR disclosure. This indicates how these elements are key factors in promoting information transparency for the benefit of shareholders and stakeholders. However, no link was found between AC size or AC financial expertise and CSRDL.

This study has significant managerial implications from a practical perspective. Jordanian policymakers and regulators (such as ASE and Securities Depository Center) could benefit from the study's insights and learn how to reform and formulate policies to encourage compliance by companies that are required to disclose CSR. This will make them more responsive to social interests because CSR disclosure has a very important role in meeting the interests of stakeholders and the company's long-term needs. Furthermore, findings from the study suggest that the ASE should review current listing requirements by putting more emphasis on CSR disclosure. It should improve the current structural and functional requirements of ACs to make them work more effectively.

The study has a few limitations. First, it used corporate annual reports as the medium through which to quantify CSR, although there are other mediums used by listed companies to communicate with their stakeholders, such as websites and corporate letters. Second, our results are based on a sample of non-financial companies, so the generalisability of the results requires including financial companies. Third, the study selected only one proxy for corporate governance, $\mathrm{AC}$, although there are other proxies are available to represent board composition and ownership structure. Despite these limitations, the evidence provided in this study makes an interesting contribution regarding the role of AC members in the practice of CSR reporting. Additionally, these insights provide fresh opportunities for further research, for example, longitudinal studies of financial companies. Finally, future research might analyse the impact of other characteristics of the $\mathrm{AC}$, such as the gender, age and educational level of the directors, multiple directorships, tenure, and remuneration.

\section{References}

Abu-Baker, N., \& Naser, K. (2000). Empirical evidence on corporate social disclosure (CSD) practices in Jordan. International Journal of Commerce and Management, 10(3/4), 18-34.

Abu Farha, E., \& Alkhalaileh, M. (2016). The relationship between corporate social responsibility's disclosure and financial performance: An empirical study of Jordanian companies listed on Amman stock exchange. Jordan Journal of Business Administration, 407(3974), 1-15. 
Abu Qa'dan, M. B., \& Suwaidan, M. S. (2019). Board composition, ownership structure and corporate social responsibility disclosure: The case of Jordan. Social Responsibility Journal, 15(1), 28-46.

Aguinis, H., \& Glavas, A. (2012). What we know and don't know about corporate social responsibility: A review and research agenda. Journal of Management, 38(4), 932-968.

Ahmed Haji, A., \& Anifowose, M. (2016). Audit committee and integrated reporting practice: Does internal assurance matter?. Managerial Auditing Journal, 31(8/9), 915-948.

Akhtaruddin, M., \& Haron, H. (2010). Board ownership, audit committees' effectiveness and corporate voluntary disclosures. Asian Review of Accounting, 18(1), 68-82.

Al-Hamadeen, R., \& Badran, S. (2014). Nature and determinants of CSR disclosure: Experience of the Jordanian public shareholding companies. European Journal of Business and Management, 6(13), 18-34.

Alazzani, A., Aljanadi, Y., \& Shreim, O. (2019). The impact of existence of royal family directors on corporate social responsibility reporting: A servant leadership perspective. Social Responsibility Journal, 15(1), 120-136.

Ali, B., \& Kamardin, H. (2018). Audit committee characteristics and real earnings management: A review of existing literature and the new avenue of research. Asian Journal of Multidisciplinary Studies, 6(12), 128-135.

Alshannag, F. M., Basah, M. Y. A., \& Khairi, K. F. (2016). The level of corporate social responsibility disclosure in Jordan. International Journal of Accounting Research, 2(12), 50-64.

Amran, A., \& Ooi, S. K. (2014). Sustainability reporting: Meeting stakeholder demands. Strategic Direction, 30(7), $38-41$.

Appuhami, R., \& Tashakor, S. (2017). The impact of audit committee characteristics on CSR disclosure: An analysis of Australian firms. Australian Accounting Review, 27(4), 400-420.

Barakat, F. S., Pérez, M. V. L., \& Ariza, L. R. (2015). Corporate social responsibility disclosure (CSRD) determinants of listed companies in Palestine (PXE) and Jordan (ASE). Review of Managerial Science, 9(4), 681-702.

Barako, D. G., Hancock, P., \& Izan, I. (2006). Relationship between corporate governance attributes and voluntary disclosures in annual reports: The Kenyan experience. Financial Reporting, Regulation and Governance, 5(1), $1-26$.

Bédard, J., Chtourou, S. M., \& Courteau, L. (2004). The effect of audit committee expertise, independence, and activity on aggressive earnings management. Auditing: A Journal of Practice \& Theory, 23(2), 13-35.

Bédard, J., \& Gendron, Y. (2010). Strengthening the financial reporting system: Can audit committees deliver?. International Journal of Auditing, 14(2), 174-210.

Chen, C. J., \& Jaggi, B. (2000). Association between independent non-executive directors, family control and financial disclosures in Hong Kong. Journal of accounting and public policy, 19(4-5), 285-310.

Chen, L., Srinidhi, B., Tsang, A., \& Yu, W. (2016). Audited financial reporting and voluntary disclosure of corporate social responsibility (CSR) reports. Journal of Management Accounting Research, 28(2), 53-76.

Crifo, P., Diaye, M.-A., Oueghlissi, R., \& Pekovic, S. (2016). What drives firms' corporate social responsibility? The role of ownership concentration. In Corporate Responsibility (pp. 183-204). London: Palgrave Macmillan.

De Klerk, M., De Villiers, C., \& Van Staden, C. (2015). The influence of corporate social responsibility disclosure on share prices: Evidence from the United Kingdom. Pacific Accounting Review, 27(2), 208-228.

Deegan, C., Rankin, M., Deegan, C., \& Rankin, M. (2002). Report environmental news: an analysis of environmental protection authority. Accounting Auditing and Accountability Journal, 15(3), 282-312.

Dhaliwal, D., Naiker, V., \& Navissi, F. (2010). The association between accruals quality and the characteristics of accounting experts and mix of expertise on audit committees. Contemporary Accounting Research, 27(3), 787-827.

Dyduch, J., \& Krasodomska, J. (2017). Determinants of corporate social responsibility disclosure: An empirical study of Polish listed companies. Sustainability, 9(11), 19-34.

Elkington, J. (2006). Governance for sustainability. Corporate Governance: An International Review, 14(6), 522-529.

Fama, E. F. (1980). Agency problems and the theory of the firm. Journal of political economy, 88(2), 288-307. 
Fama, E. F., \& Jensen, M. C. (1983). Separation of ownership and control. The Journal of Law and Economics, 26(2), 301-325.

Felo, A. J., \& Solieri, S. A. (2009). Are all audit committee financial experts created equally?. International Journal of Disclosure and Governance, 6(2), 150-166.

Forker, J. J. (1992). Corporate governance and disclosure quality. Accounting and Business Research, 22(86), 111-124.

Garas, S., \& ElMassah, S. (2018). Corporate governance and corporate social responsibility disclosures: The case of GCC countries. Critical Perspectives on International Business, 14(1), 2-26.

Garcia, E. A. d. R., de Carvalho, G. M., Boaventura, J. M. G., \& Filho, J. M. d. S. (2020). Determinants of corporate social performance disclosure: A literature review. Social Responsibility Journal. https://doi.org/10.1108/SRJ-12-2016-0224

Ghaleb, B. A. A., Kamardin, H., \& Al-Qadasi, A. A. (2020a). Internal audit function and real earnings management practices in an emerging market. Meditari Accountancy Research. https://doi.org/10.1108/MEDAR-02-2020-0713

Ghaleb, B. A. A., Kamardin, H., \& Tabash, M. I. (2020b). Family ownership concentration and real earnings management: Empirical evidence from an emerging market. Cogent Economics and Finance, 8(1), 1751488.

Greene, W. H. (2003). Econometric analysis. Pearson Education, India.

Harper, J., \& Sun, L. (2019). CEO power and corporate social responsibility. American Journal of Business, 34(2), 93-115.

Ibrahim, A. H., \& Hanefah, M. M. (2016). Board diversity and corporate social responsibility in Jordan. Journal of Financial Reporting and Accounting, 14(2), 279-298.

Ismail, K., \& Ibrahim, A. H. (2008). Social and environmental disclosure in the annual reports of Jordanian companies. Issues in Social and Environmental Accounting, 2(2), 198-210.

Jensen, M. C., \& Meckling, W. H. (1976). Theory of the firm: Managerial behavior, agency costs and ownership structure. Journal of Financial Economics, 3(4), 305-360.

Jordan Securities Commission [JSC]. (2009). Jordanian Code on Corporate Governance. Retrieved from http://jsc.gov.jo/library/634365426651890968.pdf

Kansal, M., Joshi, M., \& Batra, G. S. (2014). Determinants of corporate social responsibility disclosures: Evidence from India. Advances in Accounting, 30(1), 217-229.

Karamanou, I., \& Vafeas, N. (2005). The association between corporate boards, audit committees, and management earnings forecasts: An empirical analysis. Journal of Accounting Research, 43(3), 453-486.

Khan, A., Muttakin, M. B., \& Siddiqui, J. (2013). Corporate governance and corporate social responsibility disclosures: Evidence from an emerging economy. Journal of Business Ethics, 114(2), 207-223.

Krippendorff, K. (2018). Content analysis: An introduction to its methodology (2nd ed.). USA: Sage Publications.

Li, J., Mangena, M., \& Pike, R. (2012). The effect of audit committee characteristics on intellectual capital disclosure. The British Accounting Review, 44(2), 98-110.

Lin, Z., Xiao, J. Z., \& Tang, Q. (2008). The roles, responsibilities and characteristics of audit committee in China. Accounting, Auditing \& Accountability Journal, 21(5), 721-751.

Lisic, L. L. (2014). Auditor-provided tax services and earnings management in tax expense: The importance of audit committees. Journal of Accounting, Auditing \& Finance, 29(3), 340-366.

Madi, H. K., Ishak, Z., \& Manaf, N. A. A. (2014). The impact of audit committee characteristics on corporate voluntary disclosure. Procedia-Social and Behavioral Sciences, 164, 486-492.

Majumder, M. T. H., Akter, A., \& Li, X. (2017). Corporate governance and corporate social disclosures: A meta-analytical review. International Journal of Accounting \& Information Management, 25(4), 434-458.

Mangena, M., \& Pike, R. (2005). The effect of audit committee shareholding, financial expertise and size on interim financial disclosures. Accounting and Business Research, 35(4), 327-349. 
Othman, R., Ishak, I. F., Arif, S. M. M., \& Aris, N. A. (2014). Influence of audit committee characteristics on voluntary ethics disclosure. Procedia-Social and Behavioral Sciences, 145, 330-342.

Persons, O. S. (2009). Audit committee characteristics and earlier voluntary ethics disclosure among fraud and no-fraud firms. International Journal of Disclosure and Governance, 6(4), 284-297.

Rainsbury, E. A., Bradbury, M., \& Cahan, S. F. (2009). The impact of audit committee quality on financial reporting quality and audit fees. Journal of Contemporary Accounting \& Economics, 5(1), 20-33.

Sadou, A., Alom, F., \& Laluddin, H. (2017). Corporate social responsibility disclosures in Malaysia: Evidence from large companies. Social Responsibility Journal, 13(1), 177-202.

Said, R., Hj Zainuddin, Y., \& Haron, H. (2009). The relationship between corporate social responsibility disclosure and corporate governance characteristics in Malaysian public listed companies. Social Responsibility Journal, $5(2), 212-226$.

Setiany, E., Hartoko, S., Suhardjanto, D., \& Honggowati, S. (2017). Audit committee characteristics and voluntary financial disclosure. Review of Integrative Business and Economics Research, 6(3), 239.

Suwaidan, M. S., Al-Omari, A. M. D., \& Haddad, R. H. (2004). Social responsibility disclosure and corporate characteristics: The case of Jordanian industrial companies. International Journal of Accounting, Auditing and Performance Evaluation, 1(4), 432-447.

Tilt, C. A., \& Symes, C. F. (1999, June). Environmental disclosure by Australian mining companies: environmental conscience or commercial reality?. In Accounting Forum (Vol. 23, No. 2, pp. 137-154). Blackwell Publishers Ltd.

Ting, P. H. (2020). Do large firms just talk corporate social responsibility? The evidence from CSR report disclosure. Finance Research Letters. https://doi.org/10.1016/j.frl.2020.101476

Wachira, M., Berndt, T., \& Martinez, C. (2019). The adoption of international sustainability reporting guidelines within a mandatory framework: Lessons from South Africa. Social Responsibility Journal. https://doi.org/10.1108/SRJ-12-2018-0322

Wilmshurst, T. D., \& Frost, G. R. (2000). Corporate environmental reporting: a test of legitimacy theory. Accounting, Auditing \& Accountability Journal, 13(1), 10-26.

Wu, S., Lin, F., \& Wu, C. (2012). A study on Taiwanese corporate social responsibility and ownership structures. Corporate Ownership and Control, 9(3), 111-122.

Zaman, M., Hudaib, M., \& Haniffa, R. (2011). Corporate governance quality, audit fees and non-audit services fees. Journal of Business Finance \& Accounting, 38(1-2), 165-197.

\section{Copyrights}

Copyright for this article is retained by the author(s), with first publication rights granted to the journal.

This is an open-access article distributed under the terms and conditions of the Creative Commons Attribution license (http://creativecommons.org/licenses/by/4.0/). 